\title{
A Meta-Analysis: Utilization of E-Learning Interactive Media In Improving The Quality of Mathematical Learning
}

\author{
Salman Al Farisyi ${ }^{1}$, Sri Hastuti Noer ${ }^{2}$ \\ \{north_salman@yahoo.com ${ }^{1}$, hastuti_noer@yahoo.com² \\ Mathematics Education, Lampung University, Lampung, Indonesia ${ }^{1,2}$
}

\begin{abstract}
E-learning is a learning and knowledge tools which are carried out using computers or other electronic devices. This article is a study of several studies that discuss the use of e-learning interactive media as learning media in improving the quality of mathematics learning. This study uses a Meta-Analysis research design. In this research the database searching for international journals using semantic scholars and in searching for national journals using the search database google scholar. The studies to be included in the meta-analysis are determined based on 6 criteria and took 12 journal articles divided by 8 international journals and 4 national journals for sample in this study. Research results state that the use of e-learning media has a good impact on student learning. The benefits of using e-learning media as a learning tool where learning will become more interesting and can help students absorb the subject matter in more depth so that the quality of mathematics learning can be improved by using e-learning media.
\end{abstract}

Keywords: E-Learning, Technology, Learning Media, Quality of learning

\section{Introduction}

In the era of technological and scientific advancements, education is a means to the growth and development of the nation, so of course, education must follow the current development. Education plays an important role in creating quality individuals [1], so it is hoped that innovations in the world of education as a bridge in developing student creativity. Learning involves four components in it, such as teacher, students, environment, and media. The media are tools that mediate teachers in developing students' potential knowledge and attitudes [2]. The use of instructional media in the learning process is one way to improve the quality and effectiveness of the teaching and learning process which will ultimately be able to improve the quality of student learning outcomes [3]. Dynamic internet and computer learning media are considered to be very supportive when used in the teaching and learning process because the internet and computer learning media can explain the material better which the learning media can be loaded with a lot of material and real animations in visual or text form. can provide experience directly to students.

Most schools in Indonesia already have facilities and infrastructure of information and communication technology (ICT) available which are quite adequate, but only a few teachers use the computer-based learning media in the teaching and learning process. In general, the type of learning the use of e-learning is cheaper than conventional studies so that by 
remembering the benefits of technology, especially e-learning in teaching and learning mathematics, teachers are encouraged to use it in the classroom [4]. Based on the condition of schools in Indonesia that already support information and communication technology facilities, e-learning media is an alternative that can be used as a learning medium. So it is necessary to further research and analyze the benefits of e-learning in improving the quality of mathematics learning.

\section{Method}

This study uses a Meta-Analysis research design. Meta-analysis refers to the process of integrating the results of various studies to arrive at the synthesis of evidence [5]. This metaanalysis research is an analysis of several journal articles, this study is the result of previous research with similar problems so that we can find out the results and conclusions. Before taking several journals for analysis, the researcher first determines the titles to be discussed, then looks for journals related to the title in the search database and selects them. The search database used by researchers in searching for international journals for analysis, namely https://www.semanticscholar.org/ (semantic scholar) and in searching for national journals using the search database https://scholar.google.co.id/ (google scholar).

The search procedure to find articles related to the use of e-learning media in mathematics learning is to limit the search based on publication date, namely the last 5 years and with the keyword "Development of E-Learning media in mathematic". As a result, there are 84 articles in the semantic scholar search database and 16.700, in the google scholar search database. The studies to be included in the meta-analysis are determined based on the following criteria:

a) The study must be prepared between 2015-2020.

b) The study must be open to access.

c) Subjects that are mathematics subject and must be related to junior high school, high school, or university students.

d) Doing studies regarding the use of e-learning media in mathematics learning.

e) Development studies with a pretest-posttest control group model should be used in the study.

f) In the study, the experimental group should be taught using interactive e-learning media and the control group should be taught based on traditional methods.

So from the above criteria, the researchers took 12 journal articles divided by 8 international journals and 4 national journals to be used as references in research on the use of interactive elearning media in improving the quality of mathematics learning.

The procedure in this study was adjusted to the steps of conducting a meta-analysis suggested by David B. Wilson and George A. Kelley [6], namely: (1) Determine the problem to be studied. Topics or problems studied in the research to be carried out are the use of interactive e-learning media in learning mathematics; (2) Looking for research articles related to the topic or problem to be researched. The search was conducted from two sources, namely international journals and national journals; (3) Limiting the time span of the results of the articles that will be the source of research data. The period of research articles in this research is from 2015-2020 (4) Read the title and abstract of the research article that has been searched and see the suitability of the article content with the problem to be studied; (5) Focusing research on problems, research methodology such as the type of research used, time and place 
of research, sample and population, techniques in analyzing data and in sampling, as well as research results; (6) Comparing the findings of all studies in the article according to the results obtained; (7) Analyze the conclusions found by examining the results of the study by examining the methods and data analysis in each study so that the advantages of each study can be identified; (8) Conclude the meta-analysis based on steps 6 and 7 above.

\section{Findings and Discussions}

\subsection{Quality of Learning}

Quality of learning can be interpreted as the level of success in achieving a goal made by teachers and students in an effort to achieve optimal learning outcomes in learning. In general, the quality of learning can be observed through the achievement of learning outcomes pursued by students [7]. Daryanto states that the quality of learning is the level of achievement of learning objectives, the achievement of these objectives in the form of increased knowledge and skills, and the development of attitudes through the learning process [8]. The quality of learning in the 2005 Global EFA monitoring report has several core components, namely: what students must learn, where learning takes place, how learning takes place, and what is learned [9]. The Student Evaluation of Educational Quality Questionnaire (SEEQ) describes educational quality instruments into eight characteristics, namely: learning or academic values, instructor enthusiasm, organization or clarity, scope, group interaction, individual relationships, assignments or readings, and examinations or assessments [10]. So the quality of learning refers to the knowledge generated as a process of social construction using shared understanding and working together, as well as results that arise from a learning process [11].

\subsection{Background of E-Learning in the current era}

World Health Organization (WHO) declared a global pandemic of COVID-19 on March $11^{\text {th }}, 2020$ which affected 213 countries and regions [12]. In response to COVID-19, several countries have implemented strict social distancing measures and lockdown policies. Entering the middle of March, which is March $16^{\text {th }}, 2020$ Indonesia implemented physical distancing in the face of the Covid-19 pandemic and this was enforced in all provinces in Indonesia, which eventually led to many schools being closed, thus making students study and have activities at home. Learning activities that must still be carried out between educators and students in facing school closures, especially in Indonesia, forcing digital learning interactions to provide material and assignments that students must do at home. Teachers are required to be able to present learning using technology, or it can be called e-learning where the teaching and learning process is transferred to distance learning using Information and Communication Technology (ICT).

E-learning can be interpreted as learning and knowledge tools that are carried out by using computers or electronic devices. Hartley explained that e-learning is a type of learning that enables the delivery of learning materials to students using the internet or using other computer network media [13]. Rosenberg said that e-learning refers to the use of internet technology that functions to send a series of solutions or solutions so that it can improve skills and knowledge, as well as students' enthusiasm in learning [14]. Soekartawi defines Elearning as a general term for technology-supported learning using various teaching or 
learning tools or bridges such as telephone, audio and video recording, teleconferencing, satellite transmission, and web-based training [15].

In general, e-learning is a form of learning that allows the delivery of material to students by using electronic circuits to convey the material and content of learning, guidance, or interaction as well as e-learning can be used as a medium of distance learning. Cisco explains the philosophy of e-learning that is, e-learning can answer the challenges of the development of globalization which provides a set of tools that can enrich the value of conventional learning; e-learning is the delivery of information, communication, education, training online; e-learning has a form of content that is in harmony between content and student learning styles which will ultimately provide better results in learning; e-learning does not mean replacing conventional learning models in the classroom, but reinforcing the learning model through enriching content and developing educational technology

While the characteristics of e-learning are, utilizing the advantages of computers (digital media and computer networks); utilizing electronic technology services; where educators and students can communicate with relative ease; utilizing the learning schedule, curriculum, results of learning progress and matters relating to the administration of education can be seen at any time on the computer; is an independent teaching material, can be stored on a computer so that students and teachers can access anywhere and anytime if they need it [14].

\subsection{Previous research regarding E-Learning.}

In previous research has been conducted by researchers, namely developing interactive learning media in the form of E-Module using the application of Adobe Flash CS6. Used Adobe Flash is because the application is an application that can be used to create light and reliable 2-dimensional animation so that it is widely used to build and provide videos, music, and animation on interactive multimedia that will be made. After the product goes through the validation stage by experts and is feasible for use, then the product is tested on students in three madrasah tsanawiyah schools or the equivalent of a junior high school in Bandar Lampung, with trials consisting of 30 students in each school. With data analysis techniques in research using qualitative descriptive analysis techniques.

The instrument used has 4 answers, that's Very Good (SB) given a score of 4, Good (B) score 3, Enough (C) score 2, and Less (K) score 1. The results of the assessment score of each of these students then the average is sought and converted to questions to see the module attractiveness criteria. The conversion of the score into an assessment question by looking for the average value $(\bar{x})$, namely by the formula for the number of student scores divided by the maximum number of scores then multiplied by 4 . A score with very attractive criteria is obtained if $3.26<\bar{x} \leq 4.00$, interesting if $2.51<\bar{x} \leq 3.26$, less attractive if $1.76<\bar{x} \leq 2.51$, and very less attractive if $1.00<\bar{x} \leq 1.76$.

Based on the data analysis of the test results in the 1st school, an average of 3.29 was obtained, the results of the trial in the 2nd school have obtained an average of 3.30, then the results of the trial in the 3rd school obtained an average of 3.32, all of which reached the interpretation criteria which is very attractive. So from these data, it can be concluded that interactive learning media in the form of e-modules developed by researchers have attractive criteria to be used as student learning media so that by using them students become more enthusiastic in learning mathematics [16]. 


\subsection{Relevant research on the use of E-learning media}

Research and development of computer-based learning media or e-learning is the focus of researchers and mathematicians in improving the quality of the learning process. There are many studies on the application of technology in learning activities that emphasize the use of technology [17], where previously the use of technology in the mathematics learning process has also been recommended by the national mathematics teacher council and UNESCO has also recommended the use of technology in teaching and learning activities. The reason behind it is because mathematics is an abstract subject and will not be easily observed or felt by the senses. Therefore, it can be found that most students have difficulty understanding mathematics so that a learning medium is needed [18].

Based on several studies that have been conducted related to the use of interactive elearning media. Research by Uba Umbara et al, namely the development of interactive learning media using the hippo animator application. Research shows that the interactive media that have been developed are suitable for use in mathematics learning. So from the results of the study it is concluded that interactive learning media interventions with Computer Assisted Instruction have a fairly good impact on learning mathematics, so that the use of Computer Assisted Instruction as a learning medium plays a very significant role in supporting students' mathematics learning, especially in increasing mathematical representation skills. students, thus multimedia can be used as the main learning media in student learning activities [19], this is also supported by the results of other studies where the use of electronic-based learning media can increase students' enthusiasm in learning mathematics [20]. CAI learning media is proven to be able to encourage student interest in learning, this is because multimedia is developed in an interactive way where the media is supported by motion animation, video, sound, and images. The explanation of the mathematics material is conveyed with a simple narrative which is integrated with the display of graphics, images, and audio can improve the concentration of students in learning the concepts presented. This result is relevant to other research conducted by Yogi Udjaja et al., In his research on e-learning learning media in the form of interactive games, it was found that learning media helps students to learn mathematics interactively and attractively and is assessed to be able to convey mathematical material easily so that it supports students understanding Mathematical material [21], it shows that learning with interactive media has a very effective impact in increasing self-confidence so that it is appropriate to be applied, this is because interactive media is able to support students when learning either directly or indirectly [22].

Based on the perspective of learning information and communication technology, other research has produced results that the content of learning multimedia plays a role in focusing attention and increasing student interest in learning, this happens because the concept of subject matter in learning multimedia is supported by being interactive in facilitating student learning activities, so it is effective in optimize the achievement of the objectives of learning activities[19]. Hendikawati, Zahid, and Arifudin in their research on Android-based Computer Assisted Instruction media, which based on the results of the study concluded that the Android-based CAI is valid for use as a learning resource, is flexible, and supports student self-learning. According to various sources also CAI in various variants can have a positive impact on learning, especially regarding learning outcomes achieved by students [23]. Erdogan \& Dede compared the effects of computer-aided project-based instruction on student achievement in science and technology as well as in portfolio development. At the end of the study, the findings revealed that science and technology, as well as portfolio assessment scores from the experimental group, were significantly higher than the control group. These results 
indicate that the benefits of learning are higher when instruction is provided by computeraided project-based instruction than by traditional methods [24].

Other similar research conducted by Anton, Marlina, and Dwiyanti in the development of Student Worksheet Based E-Learning supported using Edmodo has great advantages as a medium to support mathematics learning activities, namely as a tool that makes it easier for students to learn and share knowledge so as to increase motivation to be positive towards learning [25]. The results of the research conducted revealed that students' learning attitudes using e-learning oriented worksheets were supported by Edmodo in the positive aspects of mathematics learning. This is because the first practice, which is simple and effective is used when in class, lacks time in working on questions so that it is easy to discuss, both applications can be used using a smartphone or computer and can be done online, the third can increase effectiveness in learning which saves learning time. In terms of learning students can share learning summary material, send assignments, and receive feedback from the teacher. So it was concluded learning using E-learning media based on student worksheets with edmodo can motivate students to be more active in learning so that the teaching and learning process becomes more effective.

\subsection{Why the quality of mathematics learning can be improved through the use of $E$ learning media}

From the various research results described previously, the efforts that can be made in improving the quality of mathematics learning are by implementing e-learning media in an interactive form because remembering that multimedia e-learning is interactive can stimulate students' mathematical thinking, technology has an important role in the teaching and learning process whereby using interactive learning media, teachers can explain material with more proportional thinking, starting with connections to understanding [26]. Technology-based learning is widely used because it can help the teaching and learning process following what was said by Zhang which states that students who join interactive multimedia-based learning will produce higher learning outcomes compared to learning that is less interactive or traditional so it confirms that the use of technology is one way to improve learning [27].

E-learning has several advantages, namely; colorful and entertaining, flexible in terms of time and place, results can be evaluated, support class activities, content can be accessed again repeatedly, people in different geographical parts and can benefit at the same time or at different times. Pura \& Aslan mentioned e-learning plays an important role in equalizing the level of communication between students and teachers, giving equal rights to all people, and increasing motivation for people who use it [28]. According to Sun, the rapid development of computer and internet technology has made e-learning an important learning media [29]. There is a significant increase in the need for multimedia teaching materials in e-learning because the content has proven to attract the attention and interest of students as well as by the use of multimedia e-learning based can improve students' learning outcomes by up to $85 \%$ in understanding the material being taught [30]. This improvement in learning completeness can occur because in the e-learning based media the presentation of the material description is equipped with relevant images as well as audio [31]. Besides teaching using e-learning will have a significantly higher level of mastery of the material compared to material that only uses the material in the form of written texts [32].

In the process of e-learning media is an innovation that has contributed greatly to changes in the learning process, where the learning process is not only listening to the teacher in describing material that seems boring but learning material can be visualized into various 
forms and formats that are more interactive and dynamic so that students or students will be more motivated so that it causes the interest of students to be involved in the learning process. It is undeniable that student interest in learning is one aspect that affects the quality of student learning outcomes. Umbara stated that computer-oriented learning media was proven to be able to encourage student interest in learning, this was because the media that was designed was interactive. This is also in line with the perspective of learning with information and communication technology, where the content on technology-oriented e-learning media has an influence on student enthusiasm in learning and also focuses students' attention in learning because the content of the material on the media being studied is supported interactively where supported by motion animation, video, sound, and images [19].

\section{Conclusion}

Based on the discussion in this article, it can be concluded that interactive e-learning media is one of the learning media that students can use in learning in class. The use of interactive e-learning media has a good impact on student learning. The benefits obtained from using e-learning media as a teaching and learning tool are that learning will become more interesting so that it can lead to motivation to learn from students, the teacher's method of teaching students will become more varied, which is not merely verbal communication by the teacher so students do not Being bored, students become more involved in learning activities so that the use of multimedia based on e-learning can help students absorb subject matter more deeply and increase the completeness of student learning outcomes in understanding the material being taught. Thus the quality of mathematics learning can be improved by using e-learning media.

\section{References}

[1] Hartoto T. Model Pembelajaran Kooperatif Tipe Group Investigation (Gi) Meningkatkan Aktivitas Dan Hasil Belajar. Progr Stud Pendidik Sej. 2016;4(2):131-142

[2] Sutiarso S. Optimalisasi Penggunaan Papan Tulis Dalam Meningkatkan Hasil Belajar Siswa. Proceedings of Seminar Nasional Pendidikan FKIP Universitas Lampung. 2020. 178-181

[3] Supartini M. Pengaruh penggunaan media pembelajaran dan kreativitas guru terhadap prestasi belajar siswa. Penelitian Pend IPS. 2016;10(2):277-293

[4] Setyaningrum W, Waryanto NH. Developing mathematics edutainment media for Android based on students understanding and interest. Phys Conf Ser. $2018 ; 983(1)$

[5] Basu A. How to conduct meta-analysis: a basic tutorial. 2017. 1-15

[6] Merriyana R. Meta Analisis Penelitian Alternatif bagi Guru. Pendidik Penabur. 2006;5(6):102-106

[7] Munthe FT. Meningkatkan Kualitas Pembelajaran Matematika Tentang Nilai Tempat. Perspekt Ilmu Pendidik. 2008;17(9):11-18

[8] Puspitasari PD, Suwandi S, Suhita R. Penerapan Model Pembelajaran Think Talk Write Dalam Pembelajaran Menceritakan Kembali Isi Teks Biografi Dengan Media Cetak. Bahasa Sastra dan Pengajar. 2018;6(1):232

[9] Wagner DA. Quality of education, comparability, and assessment choice in developing countries. Comp Int Educ. 2010;40(6):741-760

[10] Yang JF. Learning Styles and Perceived Educational Quality in e-Learning. Asian J Distance Educ. 2008;6(1):63-75

[11] Cabani ML, Bosch JJ. Using Concept Mapping to Improve the Quality of Learning. IGI Global;2010. Handbook of Research on Collaborative Learning Using Concept Mapping; 21 
[12] WHO. Coronavirus disease (COVID-19) pandemic. 2020

[13] Mutia I, Leonard. Kajian penerapan e-learning dalam proses pembelajaran di perguruan tinggi. Fakt Exacta, 2013;6(4):278-289

[14] Yazdi M. E-learning sebagai Media Pembelajaran Interaktif Berbasis teknologi Informasi. Ilm. Foristek. 2012;2(1):143-152

[15] Rusman. The Development of an E-Learning-Based Learning Service for MKDP Curriculum and Learning at the Indonesia University of Education. Educ Pract. 2016;7(31):83-87

[16] Farisyi SA. Pengembangan Modul Elektronik Berpendekatan Contextual Teaching Learning Pada Pokok Bahasan Aljabar Untuk Siswa MTs. UIN Raden Intan Lampung; 2018

[17] Bennison A, Goos M. Learning to teach mathematics with technology: A survey of professional development needs, experiences and impacts. Math Educ Res. 2010;22(1):31-56

[18] Nurwijayanti A, Budiyono, Fitriana L. Combining google sketchup and ispring suite 8: A breakthrough to develop geometry learning media. Math Educ. 2019;10(1)103-116

[19] Umbara U, Munir M, Susilana R, Puadi EF. Increase Representation in Mathematics Classes: Effects of Computer Assisted Instruction Development with Hippo Animator. Int Electron Math. Educ. 2019;15(2):6262

[20] Chen MJ, Lee CY, Hsu WC. Influence of mathematical representation and mathematics selfefficacy on the learning effectiveness of fifth graders in pattern reasoning. Learn Teach Educ Res. 2015;13(1):1-16

[21] Udjaja Y, Guizot VS, Chandra N. Gamification for Elementary Mathematics Learning in Indonesia. Electr Comput Eng. 2018;8(5):375-383

[22] Oktavianingtyas E, Salama FS, Fatahillah A, Monalisa LA, Setiawan TB. Development 3D Animated Story as Interactive Learning Media with Lectora Inspire and Plotagon on Direct and Inverse Proportion Subject. Phys Conf Ser. 2018;1108(1)

[23] Hendikawati P, Zahid MZ, Arifudin R. Android-based Computer Assisted Instruction development as a learning resource for supporting self-regulated learning. Int J Instr. 2019;12(3):389-404

[24] Erdoğan Y, Dede D. Computer assisted project-based instruction: The effects on science achievement, computer achievement and portfolio assessment. Int J Instr. 2015;8(2):177-188

[25] Nasrullah A, Marlina M, Dwiyanti W. Development of student worksheet-based college e-learning through Edmodo to maximize the results of learning and motivation in economic mathematics learning. Emerg Tech Learn. 2018;13(12):211-229

[26] Borovcnik M, Kapadia R. Research And Developments In Probability Education. Int Electron J. Math Educ. 2009;4(3)111-130

[27] Zhang D. Interactive Multimedia-Based E-Learning: A Study of Effectiveness. American Distance Educ. 2005;19(3):149-162

[28] Çevik H, Duman T. Analyzing the effects of E-learning on science education. Int J Instr. 2018;11(1):345-362

[29] Sun PC, Cheng HK. The design of instructional multimedia in e-Learning: A Media Richness Theory-based approach. Comput Educ. 2007;49(3):662-676

[30] Safitri M, Hartono Y, Somakim S. Pengembangan Media Pembelajaran Matematika Pokok Bahasan Segitiga Menggunakan Macromedia Flash Untuk Siswa Kelas VII SMP. Pendidikan 2013;14(2):62-72

[31] Arda, Saehana S, Darsikin. Pengembangan Media Pembelajaran Interaktif Berbasis Komputer Untuk Siswa Smp Kelas VIII. Mitra Sains. 2015;3(1):69-77

[32] Yusuf AM. Pengembangan Media Pembelajaran Berbasis Adobe Flash untuk Mata Kuliah Fisika Modern. Sains dan Pendidik Fis. 2015;11(1):57-71 